\title{
FAKTOR-FAKTOR YANG MEMPENGARUHI STRUKTUR MODAL DAN KEBIJAKAN DIVIDEN YANG TERDAFTAR DI JAKARTA ISLAMIC INDEX (JII) PERIODE 2010-20141)
}

\author{
Yulianti Dwi Puji \\ Program Studi S1 Ekonomi Islam-Fakultas Ekonomi dan Bisnis-Universitas Airlangga Fakultas \\ Email: yuliantidwi.puji@gmail.com
}

Leo Herlambang

Departemen Ekonomi Syariah-Fakultas Ekonomi dan Bisnis-Universitas Airlangga Email: leo.herlambang@gmail.com

\begin{abstract}
:
The purpose of this research is to determine the direct effects of factors that caused capital structure and dividend policy. The approach research used are quantitative with analytical techniques PLS (Partial Least Square). The approach is a quantitative approach using analytical techniques PLS (Partial Least Square). Data collection using purposive sampling method and examines a sample of 12 company that that have fixed sign position in the Jll during 2010-2014.

The results of this research show that in profitability has positive significant effect on capital structure which is indicated with t-statistic is 2,409. Liquidity has negatif not significant on capital structure which is indicated with t-statistic 1,678. Capital structure has negatif significant effect on dividend policy which is indicated with t-statistic 3,568.

Keywords : Profitability, liquidity, capital structure, and devidend policy
\end{abstract}

\section{PENDAHULUAN}

Kebijakan dividen diperlukan untuk menentukan nilai perusahaan dan prospek perusahaan di masa mendatang, namun kebijakan dividen sering menimbulkan konflik antara pemegang saham, manajemen perusahaan, dan kreditur saat penggunaan hutang. Pemegang saham menghendaki penggunaan hutang yang tinggi pada struktur modal agar dapat membagikan dividen tinggi, tetapi manajemen perusahaan dan kreditur menghendaki penggunaan tingkat hutang yang rendah untuk menjaga tingkat kesejahteraan dan menghindari transfer risiko. Tujuan dari adanya perbedaan kepentingan adalah untuk menjaga kesejahteraan dan kemakmuran masing- masing.
Bagi investor, dividen merupakan salah satu harapan terbesar pemegang saham terhadap investasinya. Namun bagi sebagian perusahaan dividen dianggap memberatkan karena perusahan harus selalu menyediakan sejumlah kas dalam jumlah yang relatif permanen untuk membayarkan dividen di masa yang akan datang, sehingga diperlukan pinjaman maupun penerbitan saham.

Banyak investor Indonesia yang ingin membentuk portofolio yang terdiri dari saham-saham yang sesuai dengan prinsip syariah sesuai dengan ketentuan dari Otoritas Jasa Keuangan. Investor muslim yang memilih melakukan investasi disaham syariah harus paham hakikat dari kegitan investasi dan bukan semata-mata

1) Jurnal ini merupakan bagian dari skripsi yang ditulis oleh Yulianti Dwi Puji, NIM: 041211431011 , yang diuji pada 9 Mei 2016 
Puji, et al/Jurnal Ekonomi Syariah Teori dan Terapan Vol. 3 No. 10 Oktober 2016: 829-842; FAKTOR-FAKTOR YANG MEMPENGARUHI STRUKTUR MODAL DAN KEBIJAKAN DIVIDEN YANG TERDAFTAR DI JAKARTA ISLAMIC INDEX (JII) PERIODE 2010-2014

mengambil keuntungan dari dividen atau capital gain yang diharapkan. Investor muslim selain melihat aspek keuntungan, perlu memperhatikan penerapan prinsip syariah dalam instrumen yang digunakan dalam investasi.

Pembayaran dividen yang dilakukan perusahaan harus menjauhi unsur riba. Seperti yang dijelaskan dalam QS. Ar Ruum 39:

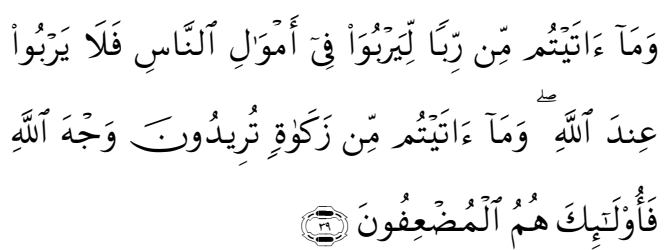

wama a ataytum min riban liyarbuwa fii amwaali alnnaasi falaa yarbue 'inda allaahi wamaa aataytum min zakaatin turiiduuna wajha allaahi faulaa-ika humu almudh'ifuuna.

Artinya: "Dan sesuatu riba (tambahan) yang kamu berikan agar dia bertambah pada harta manusia, maka riba itu tidak menambah pada sisi Allah. Dan apa yang kamu berikan berupa zakat yang kamu maksudkan untuk mencapai keridhaan Allah, maka (yang berbuat demikian) itulah orang-orang yang melipat gandakan (pahalanya)". (Q.S. Ar RuUm 30:39, Kementrian Agama Rl, 2016:806)

Manajemen sering mengalami kesulitan untuk memutuskan apakah laba yang didapatkan akan dibagikan kepada para pemegang saham dalam bentuk dividen atau menahannya untuk diinvestasikan kembali pada proyekproyek yang lebih menguntungkan. Dengan demikian kebijakan dividen harus dianalisa dalam kaitannya dengan keputusan pembelanjaan atau penentuan struktur modal secara keseluruhan. Keputusan perusahaan dalam membagikan dividen tidak terlepas dari struktur modal. Faktor-faktor yang disinyalir mempengaruhi struktur modal adalah profitabilitas dan likuiditas.

Penelitian yang dilakukan oleh Wigati (2014) menunjukkan bahwa secara simultan likuiditas berpengaruh negatif dan signifikan terhadap struktur modal. Sedangkan profitabilitas tidak berpengaruh terhadap struktur modal. Sedangkan penelitian yang dilakukan oleh Putri (2012) menunjukkan bahwa profitabilitas (Return On Assets/ROA) berpengaruh positif dan tidak signifikan terhadap struktur modal. Profitabilitas tidak berpengaruh signifikan terhadap struktur modal pada penelitian yang dilakukan oleh Julita (2013).

\section{LANDASAN TEORI}

Simpulan dari teori MM tanpa pajak adalah perusahaan menggunakan hutang atau tidak, ternyata nilai perusahaan dan biaya modal perusahaan adalah tetap. Atau dengan kata lain, nilai perusahaan yang menggunakan hutang sama dengan nilai perusahaan yang tidak menggunakan hutang. Proposisi MM I adalah proposisi di mana nilai perusahaan adalah bersifat independen terhadap struktur modalnya. Perimbangan struktur modal de/rasio) tidak mempengaruhi nilai perusahaan karena nilai asetnya sama (Home Wachowicz, 2006 dalam Ambarwati, 2010: 42). Proposisi MM II menyatakan bahwa perubahan hutang tidak akan merubah 
Puji, et al/Jurnal Ekonomi Syariah Teori dan Terapan Vol. 3 No. 10 Oktober 2016: 829-842; FAKTOR-FAKTOR YANG MEMPENGARUHI STRUKTUR MODAL DAN KEBIJAKAN DIVIDEN YANG TERDAFTAR DI JAKARTA ISLAMIC INDEX (JII) PERIODE 2010-2014

WACC. Biaya hutang memang lebih kecil dibandingkan biaya modal sendiri. Tapi semakin besar penggunaan hutang, semakin besar pula risiko sehingga biaya modal sendiri bertambah. Sedangkan pada teori MM dengan pajak menunjukkan bahwa penggunaan hutang (leverage) akan meningkatkan nilai perusahaan karena biaya bunga hutang adalah biaya yang mengurangi pembayaran pajak. Preposisi I yaitu struktur modal optimal perusahaan adalah seratus persen hutang. Preposisi II yaitu penggunaan hutang yang semakin banyak akan meningkatkan biaya modal saham.

Trade-off Theory menyatakan bahwa penggunaan hutang akan menurunkan nilai perusahaan karena kenaikan keunungan dari penggunaan hutang tidak sebanding dengan kenaikan biaya financial distress dan agency problem. (Myers, 2001:81)

Pecking Order Theory menyatakan bahwa perusahaan memprioritaskan sumber-sumber pendanaan internal ekuitas sebagai pembiayaan terakhir. Menurut pecking order theory dikutip oleh Smart et al., (2004, p.458-459), terdapat skenario urutan (hierarki) dalam memilih sumber pendanaan, yaitu sumber dana internal yang diperoleh dari laba ditahan, hutang yang paling rendah risikonya, turun ke hutang yang lebih berisiko, sekuritas hybrid seperti obligasi konversi, saham preferen, dan yang terakhir saham biasa. Teori ini menggunakan kebijakan dividen yang konstan dan perusahaan akan mengambil portofolio investasi yang lancar. Hal ini dilakukan guna menghindari hutang yang tinggi, karena semakin tinggi penggunaan sumber pendanaan eksternal, maka tingkat likuiditas perusahaan semakin rendah.

Anthony dan Govindarajan (1995) dalam Atmaja (2008) menyatakan bahwa Agency Theory ialah konsep teori keagenan adalah hubungan atau kontrak yang terjadi antara principal dan agent. Pada perusahaan yang modalnya terdiri atas saham, pemegang saham bertindak sebagai principal, dan CEO /Chief Executive Officer) sebagai agent mereka. Agency theory memiliki asumsi bahwa masing-masing individu semata-mata termotivasi oleh kepentingan dirinya sendiri sehingga menimbulkan konflik kepentingan antara principal dan agent.

Teori Dividen Tidak Relevan dari MM ialah nilai suatu perusahaan tidak ditentukan oleh besar kecilnya DPR, tapi ditentukan oleh laba bersih sebelum pajak (EBIT) dan kelas risiko perusahaan. Jadi menurut $M M$, dividen adalah tidak relevan. Biaya modal sendiri ditentukan oleh besar kecilnya laba di tahan dan besar kecilnya laba di tahan ditentukan oleh DPR maka kebijakan dividen mempengaruhi nilai perusahaan.

Teori The Bird in the Hand ialah Investor memandang dividend yield lebih pasti daripada capital gains yield. Modigliani dan Miller menganggap bahwa argumen Goldon dan Litner ini 
Puji, et al/Jurnal Ekonomi Syariah Teori dan Terapan Vol. 3 No. 10 Oktober 2016: 829-842; FAKTOR-FAKTOR YANG MEMPENGARUHI STRUKTUR MODAL DAN KEBIJAKAN DIVIDEN YANG TERDAFTAR DI JAKARTA ISLAMIC INDEX (JII) PERIODE 2010-2014

merupakan suatu kesalahan karena pada akhirnya investor akan kembali menginvestasikan dividen yang diterima pada perusahaan yang sama atau perusahaan yang memiliki risiko yang hampir sama.

Teori Perbedaan Pajak ialah menyatakan bahwa karena ada pajak terhadap keuntungan dividen dan capital gains, para investor lebih menyukai capital gains karena dapat menunda pembayaran pajak. Investor mensyaratkan suatu tingkat keuntungan yang lebih tinggi pada saham yang memberikan dividen yield tinggi, capital gains yield tinggi, dan sebaliknya.

Sesuai dengan pecking order theory, perusahaan yang memiliki tingkat keuntungan yang besar cenderung memiliki hutang yang kecil. Dimana perusahaan yang memiliki profitabilitas yang tinggi akan mendanai kegiatan operasionalnya menggunakan sumber pendanaan internal daripada sumber pendanaan eksternal. Perusahaan yang memiliki sumber pendanaan internal yang besar cenderung menggunakan laba ditahan yang besar daripada menambah hutang perusahaan karena memiliki resiko yang rendah dibandingkan menggunakan sumber pendanaan eksternal. Indikator yang digunakan dalam variabel profitabilitas yaitu Return On Asset (ROA), Return on Equity (ROE), Net Profit Margin (NPM), dan Earning per Share (EPS). $\mathrm{HI}$ : Profitabilitas berpengaruh negatif terhadap Struktur Modal.
Perusahaan yang memiliki hutang kecil cenderung memiliki kemampuan likuiditas yang tinggi. Dengan kemampuan likuiditas yang tinggi, perusahaan dapat mengurangi tingkat risiko perusahaan dengan mengurangi hutang. Sehingga perusahaan yang memiliki kemampuan likuiditas yang tinggi semakin mampu menggunakan sumber pendanaan internal dalam mendanai kegiatan operasionalnya. Indikator yang digunakan adalah Current Rasio (CR) dan Quick Rasio (QR). H2 : Likuiditas berpengaruh negatif terhadap Struktur Modal.

Menurut Sjahrial (2008:170), semakin besar hutang perusahan maka cenderung untuk membayar dividennya lebih rendah dengan tujuan untuk mengurangi ketergantungan pada pendanaan secara eksternal. Sehingga semakin besar proporsi hutang yang digunakan untuk struktur modal suatu perusahaan, maka akan semakin besar pula jumlah kewajibannya yang akan mempengaruhi besar kecilnya dividen yang akan dibagikan. Penelitian ini menggunakan indikator Debt to equity ratio (DER) dan Debt to Asset Ratio (DAR). H3 : Struktur Modal berpengaruh negatif terhadap Kebijakan Dividen.

Berdasarkan hipotesis di atas, bentuk persamaannya adalah :

$\eta 1=\gamma 1 \xi 1+\gamma 2 \xi 2+\zeta 1$

$\eta 2=\beta 1+\eta 1+\zeta 2$

Model analisis pada penelitian ini adalah: 
Puji, et al/Jurnal Ekonomi Syariah Teori dan Terapan Vol. 3 No. 10 Oktober 2016: 829-842; FAKTOR-FAKTOR YANG MEMPENGARUHI STRUKTUR MODAL DAN KEBIJAKAN DIVIDEN YANG TERDAFTAR DI JAKARTA ISLAMIC INDEX (JII) PERIODE 2010-2014

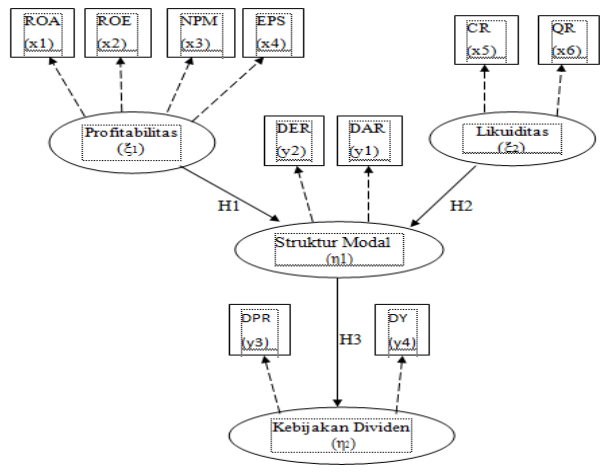

Sumber: Penulis

Gambar 1.

Model Analisis

\section{METODE PENELITIAN}

Pendekatan dalam penelitian ini adalah pendekatan kuantitatif. Variabel Profitabilitas dan Likuiditas sebagai variabel independen. Variabel struktur modal sebagai variabel intervening. Sedangkan variabel kebijakan dividen sebagai variabel dependen. Adapun definisi operasional penelitian ini:

1. Rasio profitabilitas merupakan rasio untuk menilai kemampuan perusahaan dalam mencari keuntungan. Pada penelian ini terdapat empat indikator yaitu ROA, ROE, NPM, EPS

2. Rasio likuiditas merupakan rasio yang menggambarkan

kemampuan perusahaan dalam memenuhi kewajiban jangka pendek. Terdapat dua indikator dalam penelitian ini.

3. Rasio Struktur modal merupakan penentuan komposisi modal. Pada penelian ini terdapat dua indikator yaitu DER dan DAR.

4. Rasio Kebijakan Dividen merupakan rencana tindakan yang harus diikuti dalam membuat keputusan dividen.
Pada penelian ini terdapat dua indikator yaitu DPR dan DY.

Keseluruhan data pada penelitian ini menggunakan data sekunder yang diperoleh dari laporan keuangan audit tahunan perusahaan dari website resmi Indonesia Stock Exchange (IDX). Data yang digunakan adalah laporan keuangan audit akhir tahun. Populasi dalam penelitian ini adalah perusahaan yang terdaftar pada Jakarta Islamic Index (JII). Teknik penentuan sampel yang digunakan dalam penelitian ini adalah teknik purposive sampling. Teknik purposive sampling adalah teknik penentuan sampel dengan pertimbangan tertentu (Anshori dan Iswati, 2009:105). Pertimbangan tersebut adalah perusahaan yang terdaftar secara terusmenerus di JII selama periode 2010-2014 dan mempublikasikan laporan keuangan audit tahunan periode 2010-2014, maka dapat diambil 12 perusahaan yang memenuhi kriteria. Perusahaan tersebut adalah:

Tabel 1.

Perusahaan yang terdaftar tetap pada JII periode 2010-2014

\begin{tabular}{|l|l|}
\hline No & Nama Perusahaan \\
\hline 1 & Astra Agro Lestari Tbk. \\
\hline 2 & Astra Internasional Tbk. \\
\hline 3 & Indocement Tunggal Perkasa Tbk. \\
\hline 4 & Indo Tambangraya Megah Tbk. \\
\hline 5 & Kalbe Farma Tbk. \\
\hline 6 & Lippo Karawaci Tbk. \\
\hline 7 & London Sunatera Indonesia Tbk. \\
\hline 8 & Bukit Asam (Persero) Tbk. \\
\hline
\end{tabular}


Puji, et al/Jurnal Ekonomi Syariah Teori dan Terapan Vol. 3 No. 10 Oktober 2016: 829-842; FAKTOR-FAKTOR YANG MEMPENGARUHI STRUKTUR MODAL DAN KEBIJAKAN DIVIDEN YANG TERDAFTAR DI JAKARTA ISLAMIC INDEX (JII) PERIODE 2010-2014

\begin{tabular}{|l|l|}
\hline No & Nama Perusahaan \\
\hline 9 & Semen Indonesia (Persero) Tbk \\
\hline 10 & Telekomukasi Indonesia Tbk. \\
\hline 11 & United Tractors Tbk. \\
\hline 12 & Unilever Indonesia Tbk. \\
\hline
\end{tabular}

Sumber: Bursa Efek Indonesia (data diolah)

Pengujian hipotesis penelitian dilakukan dengan pendekatan Structural Equation Model (SEM) berbasis Partial Least Square. Teknik analisis dalam penelitian ini menggunakan teknik PLS yang di dalamnya terdapat uji measurement model, yaitu validitas indikator dan reliabilitas indikator serta uji structural model, yaitu melihat korelasi antara variabel-variabel yang diukur, yang merupakan uji t partial least square.

\section{HASIL DAN PEMBAHASAN}

\section{Convergent Validity}

1. Outer Model atau Measurement Model Variabel Profitabilitas

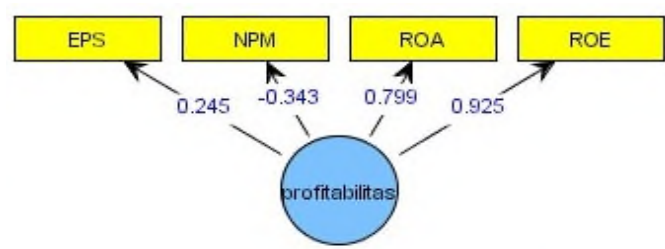

Sumber : Diolah dari Output SmartPLS Gambar 2.

Outer Loadings (Measurement Model) Tahap I

Variabel Profitabilitas

Nilai outer model atau korelasi antara indikator NPM dan EPS dengan variabel profitabilitas di bawah 0,50 atau tidak valid yang berarti indikator harus dihapus atau dikeluarkan dari perhitungan dan diolah kembali.

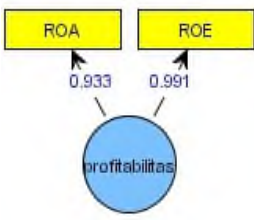

Sumber : Diolah dari Output SmartPLS Gambar 3.

Outer Loadings (Measurement Model) Tahap II

Variabel Profitabilitas

Nilai outer model atau korelasi

antara indikator dengan variabel yang secara umum sudah memenuhi convergent validity dan nilainya sudah diatas 0,5 .

2. Outer Model atau Measurement Model Variabel Likuiditas

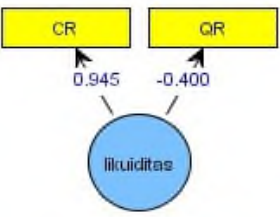

Sumber : Diolah dari Output SmartPLS Gambar 4.

Outer Loadings (Measurement Model) Tahap I

Variabel Likuiditas

Nilai outer model atau korelasi antara indikator $Q R$ dengan variabel likuiditas di bawah 0,50 atau tidak valid yang berarti indikator harus dihapus atau dikeluarkan dari perhitungan dan diolah kembali.

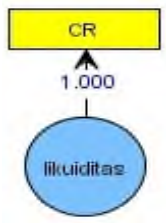

Sumber : Diolah dari Output SmartPLS Gambar 5.

Outer Loadings (Measurement Model) Tahap II Variabel Likuiditas

Nilai yang dianjurkan yakni sebesar 
Puji, et al/Jurnal Ekonomi Syariah Teori dan Terapan Vol. 3 No. 10 Oktober 2016: 829-842; FAKTOR-FAKTOR YANG MEMPENGARUHI STRUKTUR MODAL DAN KEBIJAKAN DIVIDEN YANG TERDAFTAR DI JAKARTA ISLAMIC INDEX (JII) PERIODE 2010-2014

0,50 sehingga indikator untuk variabel likuiditas tidak ada lagi yang dieliminasi dari model.

3. Outer Model atau Measurement Model Variabel Struktur Modal

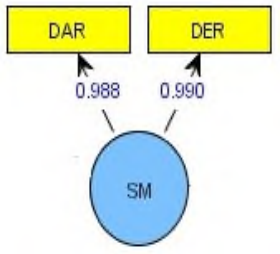

Sumber : Diolah dari Output SmartPLS Gambar 6.

Outer Loadings (Measurement Model) Tahap I

Variabel Struktur Modal

Nilai yang dianjurkan yakni sebesar 0,50 sehingga indikator untuk variabel struktur modal tidak ada lagi yang dieliminasi dari model.

4. Outer Model atau Measurement Model Variabel Kebijakan Dividen

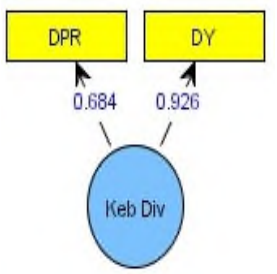

Sumber : Diolah dari Output SmartPLS Gambar 7.

Outer Loadings (Measurement Model) Tahap I

Variabel Kebijakan Dividen

Nilai yang dianjurkan yakni sebesar 0,50 sehingga indikator untuk variabel kebijakan dividen tidak ada lagi yang dieliminasi dari model

\section{Outer Model atau Measurement Model}

Berikut ini adalah hasil secara keseluruhan dari uji algorithm tahap awal dan akhir pada PLS dengan indikator- indikator yang semuanya memenuhi standar validitas.

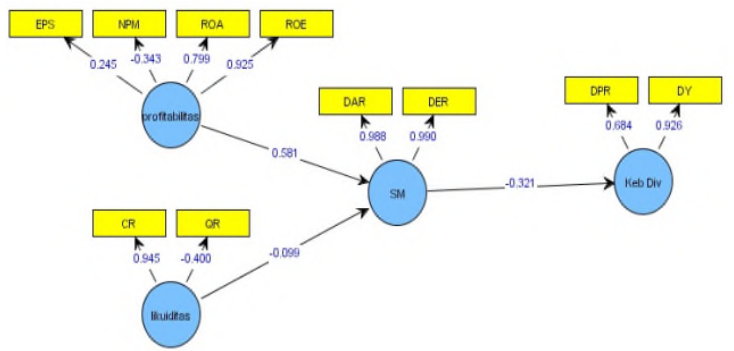

Sumber : Diolah dari Output SmartPLS

Gambar 8.

Hasil Algorithm Awal

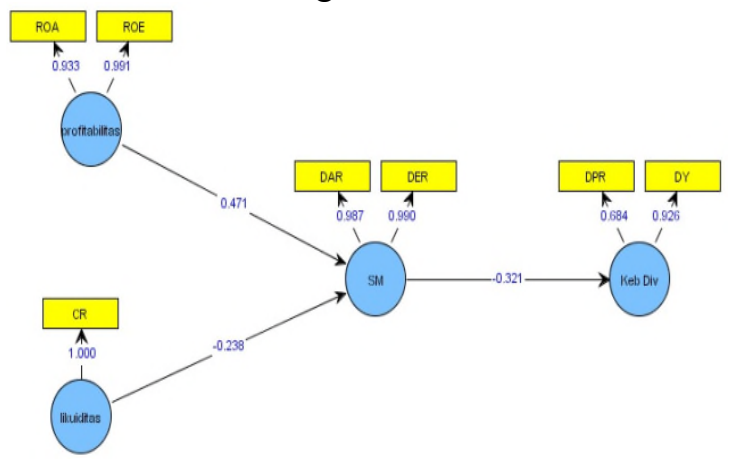

Sumber : Diolah dari Output SmartPLS

Gambar 9.

Hasil Algorithm Akhir

\section{Discriminant Validity}

Validitas diskriminan indikator dapat dilihat pada cross loading antara indikator dengan konstruknya. Pada tabel di atas, indikator mempunyai korelasi yang lebih besar terhadap konstruk masingmasing. Sehingga tidak terdapat data yang outlier.

Uji validitas dilakukan dengan mengkorelasikan skor item (component score) dengan construct score yang kemudian menghasilkan nilai outer loading. Nilai outer loading dikatakan tinggi jika komponen atau indikator berkorelasi lebih dari 0,70 dengan konstruk yang ingin diukur (Yamin dan Kurniawan, 2011 dalam Ghozali 2008). Namun 
Puji, et al/Jurnal Ekonomi Syariah Teori dan Terapan Vol. 3 No. 10 Oktober 2016: 829-842; FAKTOR-FAKTOR YANG MEMPENGARUHI STRUKTUR MODAL DAN KEBIJAKAN DIVIDEN YANG TERDAFTAR DI JAKARTA ISLAMIC INDEX (JII) PERIODE 2010-2014

demikian untuk penelitian tahap awal dari pengembangan, outer loading0,50-0,60 dianggap cukup (Ghozali, 2008). Hasil dari uji validitas dapat dilihat pada Tabel 2.

Tabel 2.

Hasil Uji Validitas

(Uji Hasil Outer Loading)

\begin{tabular}{|l|l|l|l|l|}
\hline & profit & likui & sm & div \\
\hline CR & 0.000 & 1.000 & 0.000 & 0.000 \\
\hline DAR & 0.000 & 0.000 & 0.987 & 0.000 \\
\hline DER & 0.000 & 0.000 & 0.990 & 0.000 \\
\hline DPR & 0.000 & 0.000 & 0.000 & 0.684 \\
\hline DY & 0.000 & 0.000 & 0.000 & 0.926 \\
\hline ROA & 0.933 & 0.000 & 0.000 & 0.000 \\
\hline ROE & 0.991 & 0.000 & 0.000 & 0.000 \\
\hline
\end{tabular}

Sumber : Diolah dari Output SmartPLS

\section{Uji Reliabilitas}

Ghozali (2008:42) menyebutkan bahwa suatu variabel juga bisa dianggap reliabel jika nilai composite reliability-nya diatas 0,7 . Berikut adalah Tabel composite reliability yang menunjukkan bahwa semua variabel dan dimensi adalah reliabel.

Tabel 3.

Composite Reliability

\begin{tabular}{|l|l|}
\hline & Composite Reliability \\
\hline profit & 0.962 \\
\hline likui & 1.000 \\
\hline sm & 0.989 \\
\hline div & 0.794 \\
\hline
\end{tabular}

Sumber : Diolah dari Output SmartPLS

\section{Pengujian Model Struktural (Inner Model)}

Tujuan dari uji structural model adalah melihat korelasi konstruk-konstruk yang diukur yang merupakan uji $\dagger$ dari partial least square itu sendiri.

\section{R-Square Model}

Pengujian terhadap model struktural dilakukan dengan melihat nilai Rsquare yang merupakan uji goodness-fit model.

Tabel 4.

R-Square

\begin{tabular}{|l|l|}
\hline & R-square \\
\hline Profit & 0.000 \\
\hline Likui & 0.000 \\
\hline Sm & 0.351 \\
\hline Div & 0.103 \\
\hline
\end{tabular}

Sumber : Diolah dari Output SmartPLS

Berdasarkan Tabel R Square di atas dapat diketahui bahwa, model pengaruh Profitabilitas dan Likuiditas terhadap Struktur Modal memberikan nilai R-square sebesar 0,351 yang dapat diinterpretasikan bahwa variabel Struktur Modal yang dapat dijelaskan oleh variabel Profitabilitas dan Likuiditas sebesar $35,1 \%$. Model pengaruh Struktur Modal terhadap Kebijakan Dividen memberikan nilai R-square sebesar 0,103 yang dapat diinterpretasikan bahwa variabel Kebijakan Dividen yang dapat dijelaskan oleh variabel Struktur Modal sebesar $10,3 \%$.

\section{Pembahasan}

1. Pengaruh Profitabilitas terhadap Strutur Modal

Hasil menunjukkan bahwa pengaruh profitabilitas dengan indikator ROA dan ROE berpengaruh positif signifikan terhadap struktur modal dengan koefisien parameter sebesar 0,471 dan $t$ statitik sebesar 2,409 (t-tabel signifikansi $5 \%=1,96)$. 
Puji, et al/Jurnal Ekonomi Syariah Teori dan Terapan Vol. 3 No. 10 Oktober 2016: 829-842; FAKTOR-FAKTOR YANG MEMPENGARUHI STRUKTUR MODAL DAN KEBIJAKAN DIVIDEN YANG TERDAFTAR DI JAKARTA ISLAMIC INDEX (JII) PERIODE 2010-2014

Penelitian ini sesuai dengan teori yang dijelaskan sebelumnya yaitu teori MM dengan pajak dan trade-off theory. Perusahaan-perusahaan yang mempunyai laba yang besar cenderung akan meminjam karena adanya benefit berupa tax-shield. Semakin tinggi laba, semakin credible perusahaan tersebut untuk mendapatkan pinjaman. Perusahaan-perusahaan dengan tingkat profitabilitas yang tinggi tentu akan berusaha mengurangi pajaknya dengan cara meningkatkan rasio hutangnya, sehingga tambahan hutang tersebut akan mengurangi pajak.

Pada perusahaan (emiten saham syariah) yang masuk perhitungan di Jll tahun 2010-2014 menyatakan bahwa hubungan positif profitabilitas dengan struktur modal. Sesuai dengan firman Allah pada surat At Taubah ayat 34

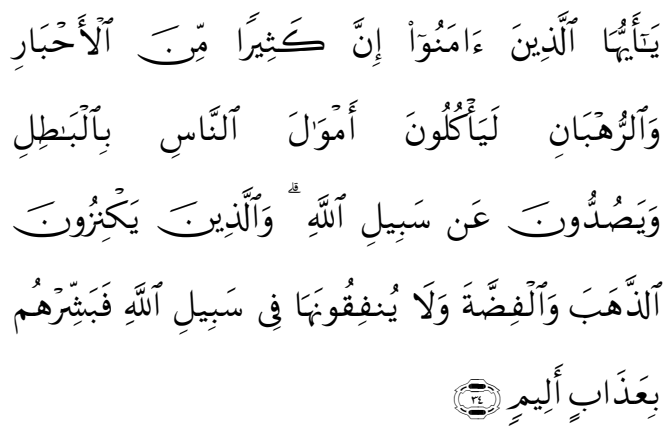

yaa ayyuhaa alladziina aamanuu inna katsiiran mina al-ahbaari waalrruhbaani laya/kuluuna amwaala alnnaasi bialbaathili wayashudduuna 'an sabiili allaahi waalladziina yaknizuuna aldzdzahaba waalfidhdhata walaa yunfiquunahaa fii sabiili allaahi fabasysyirhum bi'adzaabin aliimin

Artinya: "Hai orang-orang yang beriman, Sesungguhnya sebahagian besar dari orang-orang alim Yahudi dan rahib-rahib Nasrani benar-benar memakan harta orang dengan jalan batil dan mereka menghalanghalangi (manusia) dari jalan Allah. Dan orang-orang yang menyimpan emas dan perak dan tidak menafkahkannya pada jalan Allah, Maka beritahukanlah kepada mereka, (bahwa mereka akan mendapat) siksa yang pedih". (Q.S. At Taubah 9:34, Kementrian Agama Rl, 2016:367)

Shihab (2002: 80) menjelaskan

bahwa:

Salah satu aspek kemukjizatan al Quran tentang emas dan perak, dijadikan Allah sebagai dasar penetapan nilai vang dan alat tukar perdagangan, ayat ini tidak mengecam semua yang mengumpulkan harta untuk masa depan. Kecaman ditujukan kepada mereka yang menghimpun tanpa menafkahkan di jalan Allah.

Dalam kaitannya dengan profitabilitas adalah Islam sangat menganjurkan bisnis/perdagangan. Uang yang berputar untuk produksi akan dapat menimbulkan kemakmuran dan kesehatan ekonomi masyarakat.

2. Pengaruh Likuiditas terhadap Struktur Modal

Hasil menunjukkan bahwa pengaruh likuiditas dengan indikator $C R$ berpengaruh negatif tidak signifikan terhadap struktur modal dengan koefisien parameter sebesar -0,238 dan t-statitik sebesar 1,678 (t-tabel signifikansi 5\%=1,96).

Pengaruh variabel likuiditas terhadap variabel struktur modal yang tidak signifikan berbeda dengan teori yang sudah ada. Hal ini disebabkan oleh fakta bahwa tidak semua perusahaan 
Puji, et al/Jurnal Ekonomi Syariah Teori dan Terapan Vol. 3 No. 10 Oktober 2016: 829-842; FAKTOR-FAKTOR YANG MEMPENGARUHI STRUKTUR MODAL DAN KEBIJAKAN DIVIDEN YANG TERDAFTAR DI JAKARTA ISLAMIC INDEX (JII) PERIODE 2010-2014

yang memiliki likuiditas yang baik akan meminjam dana pada pihak ketiga. Sebagian perusahaan mempertimbangkan prospek industri, insentif bunga dari pemerintah dan suku bunga pinjaman bank. Hal ini berarti perusahaan atau manajemen tidak terlalu mempertimbangkan faktor likuiditas dalam menentukan struktur modalnya.

Hasil penelitian ini juga sesuai oleh Pecking Order Theory. Dana internal adalah pilihan pendanaan pertama bagi perusahaan. Perusahaan dengan tingkat likuiditas tinggi mampu menghimpun modal sendiri yang cukup untuk melakukan aktivitas operasi perusahaan dan baru mengunakan dana eksternal saat utang dilakukan. Semakin likuid suatu perusahaan, memungkinkan jumlah utang dapat ditekan dan jumlah modal sendiri bertambah. Hal ini dapat menurunkan perbandingan struktur modal.

Pada perusahaan yang termasuk dalam JII adalah perusahaan yang mempunyai tingkat likuiditas yang tinggi, yaitu perusahaan yang mampu membayarkan kewajiban-kewajiban jangka pendeknya. Al quran menjelaskan bahwa setiap manusia wajib melaksanakan kewajibannya sesuai dengan firman Allah pada surat surat An Nahl ayat 91

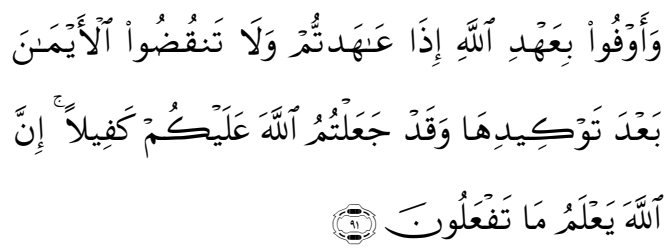

Wa aufuu bi'ahdi illahi idzaa 'hadattum walaa tanqudhue alaimaana ba'da taukiidihaa wa qadja'altum allaha 'alaikum kafiilan, inna allaha ya'lamu maataf'aluun.

Artinya: "Dan tepatilah perjanjianmu apabila kamu berjanji dan janganlah kamu membatalkan sumpah-sumpah itu, sesudah meneguhkannya, sedang kamu telah menjadikan Allah sebagai saksimu. Sesungguhnya Allah mengetahui apa yang kamu perbuat."

(Q.S. An Nahl 16:91, Kementrian Agama RI, 2016:529)

Shihab (2002: 704) menjelaskan

bahwa:

Tepatilah janji yang telah kalian buat atas nama diri kalian sendiri dengan mempersaksikan Allah untuk menepatinya selama tidak bertentangan dengan syariat. Janganlah kalian merusak sumpah dengan melanggarnya setelah sumpah itu dikukuhkan dengan menyebut nama Allah dan keinginan kuat untuk melaksanakannya. Sungguh kalian telah mengetahui bahwa Allah akan menjamin pelaksanaan janji dan sumpah tersebut. Dia Mahaperiksa dan Maha Mengawasi diri kalian. Peganglah janji dan sumpah kalian. Allah Mahatahu apakah kalian benarbenar menepati janji atau mengingkarinya dan akan memberi balasan atas perbuatan kalian.

Kaitannya pada variabel likuiditas yang terdaftar di Jll adalah perusahaan ini hendaknya memenihi kewajibankewajibannya karena sesungguhnya kita telah menjanjikan segala sesuatu harus segera kita penuhi. Allah akan melaknat orang yang tidak menepati janji yang diucapkannya. 
Puji, et al/Jurnal Ekonomi Syariah Teori dan Terapan Vol. 3 No. 10 Oktober 2016: 829-842; FAKTOR-FAKTOR YANG MEMPENGARUHI STRUKTUR MODAL DAN KEBIJAKAN DIVIDEN YANG TERDAFTAR DI JAKARTA ISLAMIC INDEX (JII) PERIODE 2010-2014

3. Pengaruh Struktur Modal terhadap Kebijakan dividen

Hasil menunjukkan bahwa pengaruh struktur modal dengan indikator DPR dan DY berpengaruh negatif signifikan terhadap struktur modal dengan koefisien parameter sebesar -0,238 dan t-0,321 statitik sebesar 3,586 (t-tabel signifikansi $5 \%=1,96$ ).

Hasil penelitian ini sesuai dengan hasil penelitian dari (Taranto, 2002 dan Noronha, 1996 dalam Dewi 2011) yang menyatakan semakin besar ketergantungan perusahaan terhadap dana eksternal (hutang) semakin intensif pengawasan oleh penyedia dana eksternal (kreditur) terhadap kinerja manajemen, sehingga memperkecil potensi masalah keagenan (agency problem) antara manajer dengan pemegang saham. Dengan semakin kecilnya agency problem tersebut maka ketergantungan perusahaan kepada dividen sebagai sarana monitoring semakin kecil.

Struktur modal islami mampu meyakinkan investor menanamkan vangnya pada saham yang termasuk dalam JII. Perusahaan dipercaya mampu mengelola dana investor sesuai dengan syariat islam. Syariat tidak pernah melarang hal-hal yang bermanfaat. Akan tetapi yang dilarang syariat hanya hal-hal yang membahayakan. Hutang akan lebih baik jika tidak menggunakan riba meskipun dengan alasan bahwa hutang dipergunakan untuk aktivitas produktif.
Sehingga biaya dari hutang hendaknya diganti dengan sistem yang lebih Islami yakni dengan marjin atau bagi hasil.

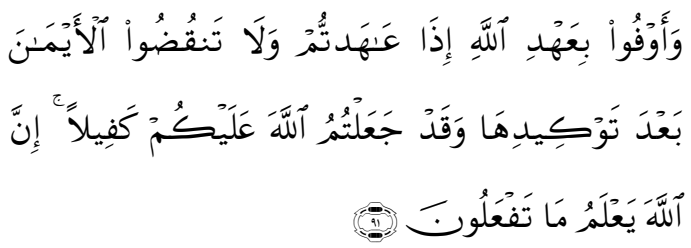

wa-'awfū bi- 'ahdi llāhi 'idhā 'āhadtum wa-lā tanqudū l-'aymāna ba'da tawkīdihā wa-qad ja altumu Ilāha alaykum kafilan inna llāha ya lamu mā taf'alūn

Artinya: "Dan tepatilah perjanjianmu apabila kamu berjanji dan janganlah kamu membatalkan sumpah-sumpah itu, sesudah meneguhkannya, sedang kamu telah menjadikan Allah sebagai saksimu. Sesungguhnya Allah mengetahui apa yang kamu perbuat." (Q.S. An Nahl 16:91, Kementrian Agama $\mathrm{Rl}, 2016: 529$ ) bahwa:

Shihab (2002: 704) menjelaskan

Tepatilah janji yang telah kalian buat atas nama diri kalian sendiri dengan mempersaksikan Allah untuk menepatinya selama tidak bertentangan dengan syariat. Janganlah kalian merusak sumpah dengan melanggarnya setelah sumpah itu dikukuhkan dengan menyebut nama Allah dan keinginan kuat untuk melaksanakannya. Sungguh kalian telah mengetahui bahwa Allah akan menjamin pelaksanaan janji dan sumpah tersebut. Dia Mahaperiksa dan Maha Mengawasi diri kalian. Peganglah janji dan sumpah kalian. Allah Mahatahu apakah kalian benarbenar menepati janji atau mengingkarinya dan akan memberi balasan atas perbuatan kalian.

Oleh karena itu, investor dalam melihat perusahaan (emiten saham syariah) hendaknya tidak melihat 
Puji, et al/Jurnal Ekonomi Syariah Teori dan Terapan Vol. 3 No. 10 Oktober 2016: 829-842; FAKTOR-FAKTOR YANG MEMPENGARUHI STRUKTUR MODAL DAN KEBIJAKAN DIVIDEN YANG TERDAFTAR DI JAKARTA ISLAMIC INDEX (JII) PERIODE 2010-2014

kemampuan perusahaan hanya karena kemampuannya dalam membayar bunga. Tetapi juga melihat aspek-aspek lain seperti peluang usaha dimasa depan, ukuran perusahaan, profitabilitas perusahaan dan perlu juga melihat kesungguhan pemilik dalam melunasi hutang yang dimilikinya.

\section{v. SIMPULAN}

Berdasarkan hasil penelitian yang telah dilakukan, maka didapatkan kesimpulan pengaruh profitabilitas dan likuiditas terhadap struktur modal dan kebijakan dividen yang masuk perhitungan di Jakarta Islamic Index periode 2010-2014. Kesimpulan yang didapatkan didalam penelitian diantaranya adalah :

1. Profitabilitas berpengaruh positif signifikan terhadap struktur modal dimana semakin besar profitabilitas maka semakin meningkat struktur modal perusahaannya. Perusahaan melakukan ekspansi untuk diinvestasikan pada kegiatan produksi yang membutuhkan banyak dana untuk mendorong peningkatan laba di masa yang akan datang. Perusahaan dengan laba yang tinggi semakin diminati oleh investor karena investor berharap perusahaan akan memberikan return yang tinggi di masa yang akan datang

2. Likuiditas mempunyai pengaruh negatif namun tidak signifikan. Hal ini terjadi karena tidak semua perusahaan yang memiliki likuiditas yang baik akan meminjam dana pada pihak ketiga. Sebagian perusahaan mempertimbangkan prospek industri, insentif bunga dari pemerintah dan suku bunga pinjaman bank.

3. Struktur Modal mempunyai pengaruh negatif signifikan terhadap kebijakan dividen dimana semakin tinggi Struktur Modal yang ada pada perusahaan, maka akan menurunkan Dividen. Pembayaran dividen yang tinggi akan memperbesar beban tetap perusahaan sehingga menyebabkan hutang lebih beresiko dan karenanya akan menurunkan nilai dari hutang tersebut

Berdasarkan penelitian ini dari pendahuluan hingga hasil dan pembahasan, terdapat beberapa saran sebagai berikut.

1. Bagi pemerintah

Pemerintah harus lebih tegas dalam mengawasi rasio kevangan yang berkaitan dengan strukutur modal pada perusahaan di Jakarta Islamic Index dengan cara mengevaluasi kinerja dan kriteria yang dikategorikan syariah sesuai peraturan Bapepam-LK.

2. Bagi investor

Bagi investor yang menginginkan pembagian return yang tinggi dan risiko stabil maka disarankan untuk berinvestasi pada perusahaan yang tergabung dalam Jakarta Islamic Index karena termasuk kriteria syariah dimana perusahaan beroperasi pada kegiatan yang halal 
Puji, et al/Jurnal Ekonomi Syariah Teori dan Terapan Vol. 3 No. 10 Oktober 2016: 829-842; FAKTOR-FAKTOR YANG MEMPENGARUHI STRUKTUR MODAL DAN KEBIJAKAN DIVIDEN YANG TERDAFTAR DI JAKARTA ISLAMIC INDEX (JII) PERIODE 2010-2014

sesuai peraturan yang ditetapkan DSNMUI.

3. Bagi Penelitian Selanjutnya

Penelitian ini diharapkan dapat dijadikan bahan bagi penelitian selanjutnya sehingga saran yang dapat diberikan adalah:

a. Karena penelitian ini hanya meneliti dua variabel independen, yaitu profitabilitas dan likuiditas saja struktur modal dan kebijakan dividen sehingga untuk penelitian selanjutnya disarankan untuk menambah variabel lain yang terkait dengan struktur modal dan kebijakan dividen. Terutama variabel keuangan yang sesuai dengan keuangan Islam.

b. Sampel perusahaan di Jakarta Islamic Index yang sedikit sehingga penelitian terbatas hanya 30 perusahaan dan hasil yang digunakan sesuai kriteria penulis hanya 12 perusahaan sehingga saran untuk penelitian selanjutnya tidak menggunakan Jakarta Islamic Index sebagai subyek penelitian melainkan menggunakan Indeks Saham Syariah Indonesia (ISSI).

\section{DAFTAR PUSTAKA}

Ambarwati, Sri Dewi Ari. 2010. Manajemen Kevangan Lanjut. Yogyakarta: Graha Ilmu.

Anshori, Muslich dan Sri Iswati. 2009. Metodologi Penelitian Kuantitatif. Surabaya: Universitas Airlangga.
Atmaja, Lukas Setia. 2008. Teori dan Praktik Manajemen Keuangan. Yogyakarta: ANDI.

Dewi, Made Pratiwi. 2011. Pengaruh struktur Modal dan Struktur Kepemilikan Terhadap Free Cash Flow dan Kebijakan Dividen pada Perusahaanperusahaan yang Go Publik di Bursa Efek Indonesia. Universitas Udayana. Tesis yang diterbitkan.

Ghozali, Imam. 2008. Structural Equation Modelling: Metode alternatif dengan PLS. Edisi Kedua. Semarang: Badan Penerbit Universitas Diponegoro.

Julita. 2013. Pengaruh Profitabilitas, dan Tingkat Pertumbuhan Penjualan Terhadap Struktur Modal pada PT Perkebunan Nusantara III (Persero) Medan. Skripsi diterbitkan. Universitas Negeri Yogyakarta.

Kementerian Agama RI. 2015. Al-Qur'an dan Terjemahnya. Solo: PT Tiga Serangkai Pustaka Mandiri

Myers, Stewart C. 2001. Capital Structure. The Journal of Economic Prespectives, Vol. 15, No. 02.

Sjahrial, Darmawan. 2008. Manajemen Kevangan. Edisi Kedua. Jakarta: Mitra Wacana Media.

Putri, Meidera Elsa Dwi. 2012. Pengaruh Profitabilitas, Struktur Aktiva, dan Ukuran Perusahaan Terhadap Struktur Modal dapa Perusahaan Manufaktur Sektor Industri Makanan dan Minuman yang Terdaftar di Bursa Efek Indonesia (BEI). Fakultas Ekonomi Universitas Negeri 
Puji, et al/Jurnal Ekonomi Syariah Teori dan Terapan Vol. 3 No. 10 Oktober 2016: 829-842; FAKTOR-FAKTOR YANG MEMPENGARUHI STRUKTUR MODAL DAN KEBIJAKAN DIVIDEN YANG TERDAFTAR DI JAKARTA ISLAMIC INDEX (JII) PERIODE 2010-2014

Padang. Jurnal Manajemen, Volume 01, Nomor 01.

Sihab, M. Quraish. 2002. Tafsir Al-Misbah. Jakarta: Lentera Hati

Smart, S.B., W.L. Megginson and L.J. gitman. 2004. Corporate Finance. 2nd Edition. Mason: Thomson.

Wigati, Tias Penget. 2014. Analisis Faktor yang Mempengaruhi Struktur Modal dengan Ukuran Perusahaan sebagai Variabel Moderating (Pada Perusahaan Property dan Real Estate yang Terdaftar di Bursa Efek Indonesia Periode 2008-2012). Skripsi diterbitkan. Universitas Diponegoro. 